\title{
Kirjastojen yhteiskunnallinen vaikuttavuus ja digitaalinen humanismi - muistoja IFLA-kesästä 2017
}

Jarmo Saarti

IFLA-seminaarini alkoivat tänä vuonna Berliinin digitaalista humanismia koskevalla satelliittiseminaarilla Digital humanities: Opportunities and risks - connecting libraries and research. Seminaarissa käsiteltiin erityisesti ihmistieteiden aineistojen digitointia, digitoitujen aineistojen tutkimusta ja aihepiiriiin liittyvien välineiden kehittämistä sekä kirjastoille että tutkijoille.

Digitaaliset aineistot tarkoittavat nykyään neljää kokonaisuutta: digitoitua aineistoa, aineistojen digitaalisia metatietovarantoja, digitaalisena syntyneitä dokumentteja ja internetin sisältämää muuta digitaalista aineistoa. Digitaalisille aineistoille on ominaista, että ne muuttuvat nopeasti, ovat teknologiariippuvaisia ja eri osa-alueilla on omat haasteensa ja kehittämistarpeensa. Digitaalinen aineisto antaa mahdollisuuden myös tutkia humanistista aineistoa tietotekniikan käytössä olevien tutkimusmenetelmien kaltaisesti: analysoida algoritmeilla digitaalista korpusta ja katsoa, mitä tuloksia sitä kautta löytyy.

Merkittävä kirjastojen työ näyttää olevan erilaisten digitaalisten aineistokokonaisuuksien luominen ja tähän liittyvä metadatatyö. Tässä on erilaisia lähestymistapoja. Laajimpia hankkeita ovat kansalliskirjastojen kattavat digitointi- ja haravointiprojektit, joilla pyritään hallitsemaan kaikki mahdollinen digitaalisessa muodossa oleva aineisto. Suppeimmillaan digitaaliset kokoelmat käsittelevät yhden tekijän tai yhden aihealueen digitaalisten aineistojen kokoelmaa. Tosin suppeus on tässä hämäävää: Delphine Vernozy ja Paule Demoliere Sorbonnen yliopistosta esittelivät Guillaume Apollinairen tuotantoon liittyvää kokoelmaa, jossa pyritään kokoamaan kaikki Apollinairen tuotantoon ja sen tulkintoihin liittyvät dokumentit. Intertekstuaalisessa maailmassa yk- sittäinen runo saa mukaansa valtavan määrän erilaista dokumentaatiota.

Digitaalinen kokoelma antaa mahdollisuuden linkittää erityyppisiä aineistoja - olipa aineisto sitten käsikirjoituksia, tekstien eri versioita, näytelmiä ja taidemaalarien kuvituksia jne. Teoreettisesti sanottuna on mahdollista luoda kontekstuaalinen metateksti kulttuurisesta ikonista kuten Apollinairesta, jonka tuotanto on vaikuttanut laajasti eurooppalaiseen kulttuurielämään ja historiaan.

Päivien esityksessä korostettiin myös metadatan laadun ja metadataformaattien luomisen tärkeyttä. Standardien ja käytänteiden tilanne on sekava. Lisäksi tekniikkojen ja uusien dokumenttityyppien nopea syntyminen ja kehittyminen aiheuttaa sen, että kirjastot tuntuvat jäävän koko ajan jälkeen tässä kilpajuoksussa. Merkittävä havainto oli Ranskan kansalliskirjaston Emmanuelle Bermésin esittämä: Kun tutkijoiden työ syvenee digitaalisten aineistojen analyysissa, näyttää heidän kokemustensa mukaan siltä, että kirjastojen tekemälle rikkaalle kuvailulle ja dokumentteja tarkasti analysoivalle kuvailuformaatille ja kuvailutyön tuottamalle rikkaalle metadatalle on suuri tarve. Aineistomassojen analysointi on nopeampaa ja analyyttisempää huolellisesti tehdyn kuvailudatan kautta.

Michael Gasser Zürichin ETH:n kirjastosta esitti, että digitaalisen ympäristön mahdollistaman joukkoistamisen suurin teho saadaan aikaan täsmäjoukkoistamisella: Gasser kollegoineen oli lähettänyt sveitsiläisen ilmailun kuvakokoelman kommentointipyynnön suoraan lentäjille ja muille lentoliikenteessä mukana työskenneille henkilöille. Näin he olivat saaneet parannettua aineistonsa kuvailua. Aineistot kannattaa 


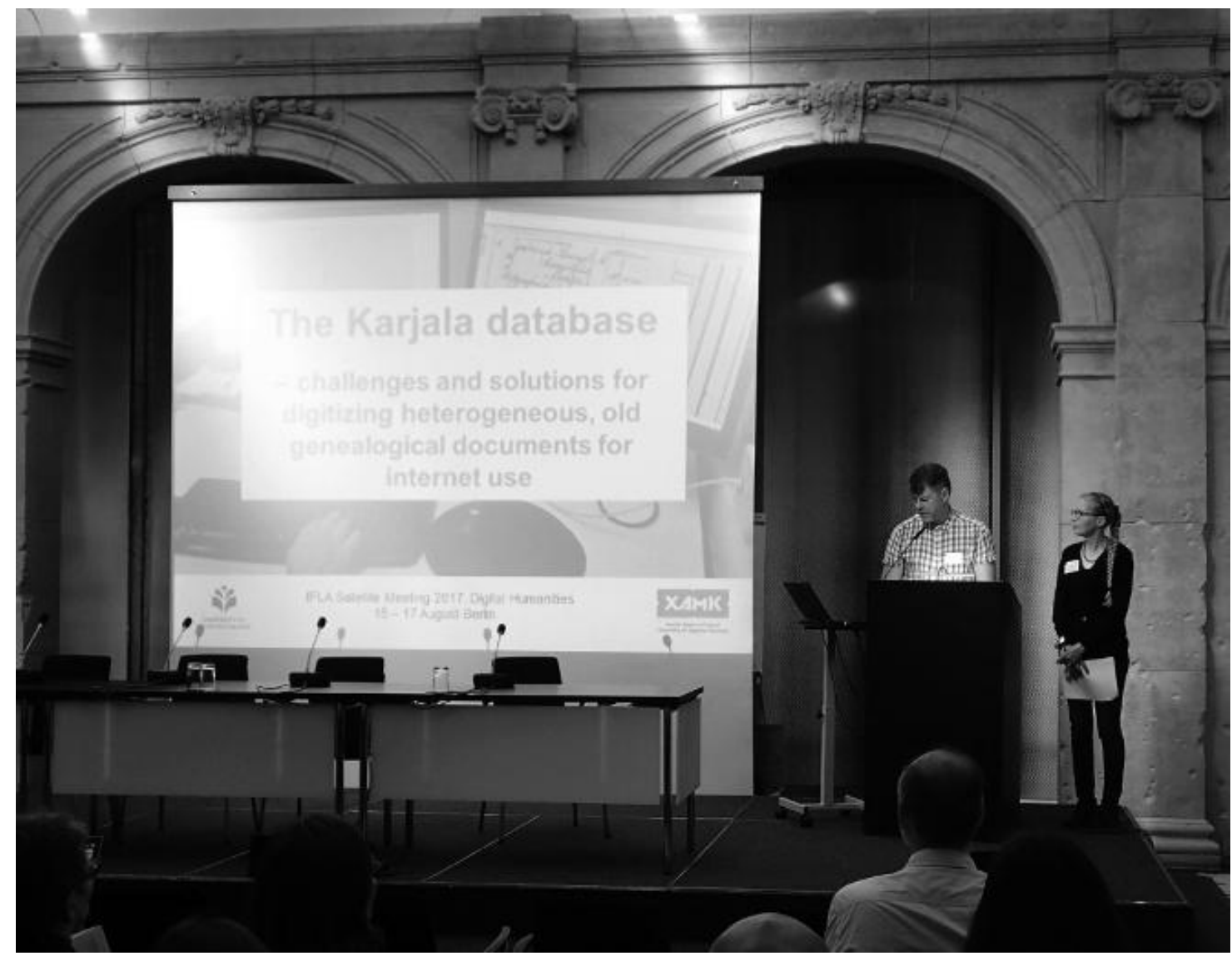

Karjala-tietokantaa esittelemässä Berliinissä

avata niiden palveluiden kautta, missä suurin osa käyttäjistä liikkuu: kuvien saaminen wikicommons-tyyppiseen käyttöön lisää Gasserin mukaan näkyvyyttä laajemmalle kuin kirjastojen tietokantojen ja sivustojen kautta jakelu. Lisäksi tarinallistaminen lisää aineistojen käyttöä: digitoitujen kuvien esittäminen ja liittäminen kerronnalliseen kehykseen saa myös niille lisää käyttäjiä.

\section{Kirjastot, solidaarisuus ja yhteiskunta}

Tämän vuoden IFLAn pääkonferenssi järjestettiin Wrocławissa, Puolassa. Konferessin teema oli ajankohtainen ja Puolan lähihistoriaan sopiva: kirjastot, solidaarisuus ja yhteiskunta. IFLAssa tematiikka näkyy myös vaikuttamisen suuntaamisessa YK:n 2030 ohjelman mukaisesti, jossa tavoitteena on kestävän kehityksen ja yhteiskunnallisen vaurauden ja vakauden kehittäminen koko maailmassa.

IFLAn uuden strategiatyön ja organisaation uudistamisen myötä järjestö on entistä enemmän korostanut kirjastojen ja niiden tekemän työn näkyvyyden ja vaikuttavuuden lisäämistä yhteiskunnassa. Solidaarisuuden merkitystä korostaa kirjastojen rooli tasa-arvoisen pääsyn takaamisesssa dokumentoituun tietoon kaikille maailman ihmisille. Digitaalinen kuilu on syntymässä myös hyvinvoiviin maihin: eriarvoisuus näkyy niiden välillä, jotka osaavat hakea tietoa ja niiden, joiden tiedonhakutaidot ovat heikot. Suomessakin on viime aikoina keskusteltu runsaasti lukutaidon heikkemisestä ja sen vaikutuksesta erityisesti poikien asemaan yhteiskunnassa. Tulevaisuuden visiot passiivisesta kuluttajaluokasta ja aktiivisesta luovasta luokasta näyttävät alkavan toteutua.

Parhaillaan käynnissä oleva IFLA Global Vision -keskustelu on hyvä esimerkki seuran strategian 
ja vaikuttamistyön jalkauttamisesta koko yhteiskuntaan ja kirjastokentälle. Keskustelun tavoite on löytää kirjastoalalle yhteisiä arvoja ja vaikuttamisen mahdollisuuksia ja samalla markkinoida kirjastojen osaamista kansallisille ja poliittisille päättäjille. IFLA on jalkauttanut visiokeskustelun sekä verkon kautta tapahtuvaksi osallistamiseksi että paikallisten tapahtumien kautta tapahtuviksi keskustelukohtaamisiksi.

\section{Digitalisoituva maailma ja aineistojen moninaisuus}

Aineistojen löydettävyys nousi esille kuvailuja aineistojen hallintaan liittyvissä esityksissä. Richard E. Sapon-White Oregon State yliopistosta esitteli työtään, jossa hän oli analysoinut ja tarkentanut alkuperäiskansojen nimistöä Kongressin sanastossa.

Hänen mukaansa virallisissa sanastoissa vastaja alakulttuurit näkyvät huonosti ja usein valtakulttuurin kautta tulkittuina. Yksi syy tähän on se, että esimerkiksi intiaaniheimojen määrittely kulttuurin sisällä on ollut vaihtelevaa ja perustunut moninaisiin käsityksiin yhteisöistä ja niiden muodostumisesta. Sanastoja ja sisällönkuvailua tulee kehittää niin, että kulttuurien rikkaus ja erilaiset tulkintatavat pystytään säilyttämään.

Vastaava haaste on Siri Gaskin mukaan saamelaisessa aineistossa, jonka bibliografiatyötä hän esitteli. Saamelaiset ovat hänen mukaansa alkuperäiskansa, joka ei asetu nykyisten valtioiden rajojen sisälle. Eri valtioiden alueilla elävät kansat eivät voi tulla kuvatuksi nykyisillä, yhden valtakulttuurin mallien mukaan rakennetuilla välineillä. Silmiä avaava harjoitus on verrata esimerkiksi Kongressin sanaston, YSOn ja Wikipedian tulkintaa saamelaiskulttuurin osa-alueista.

Ajattelin näiden esitysten antamaa haastetta myös nykyiseen ontologiapuheeseen suhteutettuna, joka ainakin minun silmissäni näyttää jonkin valtakulttuurin tai -näkemyksen mukaisen vallitsevan tulkinnan mukaan rakennetulta. Jatkossa on tärkeää, että ontologiatyö mahdollistaa erilaisia tulkintoja ja näkemyksiä sisällöistä ja kulttuu- reista. Kultturien ja sisältöjen moninaisuus ei saa enää kadota metadatatyössä.

Kamil Pawlicki Puolan kansalliskirjastosta puolestaan esitteli heidän genreillä rikastamaansa kansallisbibliografiakuvailutyötä. Kuvailun kattama alue on laajenemassa ja rikastumassa käsitteellisesti. Tähän on syytäkin, koska dokumenttien lukumäärän jatkuva kasvaminen asettaa vaateen entistä analyyttisemmälle ja syvemmälle menevälle kuvailulle aineistojen löytymisen varmistamiseksi. Kansalliskirjastojen bibliografioiden yhteiset käytänteet alkavat myös muotoutua, mikä on edellytys linkitetyn datan käytölle kuvailutyössä.

\section{YK:n kestävän kehityksen 2030 ohjelma ja kirjastojen rooli siinä}

IFLAn strategisena tavoitteena on sitoutua YK:n kestävän kehityksen ohjelmaan, jonka tavoitteena on vuoteen 2030 mennessä rakentaa tasa-arvoinen ja kestävälle kehitykselle perustuva maailma.

Kirjastojen keskeinen rooli liittyy ohjelmassa erityisesti tavoitteeseen neljä "Taata kaikille kattava ja tasa-arvoinen laadukas koulutus ja edistää elinikäistä oppimista”. Kirjastojen rooli liittyy informaatioyhteiskunnassa esitettyihin tavoitteisiin takaamalla tietoaineistojen saavutettavuus. Osaamiseen perustuva yhteiskunta voi rakentua vain, jos tietoaineistot ja kirjastojen muut resurssit ovat avoimesti ja kattavasti kaikkien saatavilla. Ei myöskään pidä unohtaa äidinkielisten aineistojen tärkeyttä kaikilla kielillä, myös niillä, joilla ei vielä kirjoitettua kieltä ja kulttuuria ole olemassa.

YK:n ohjelma rakentuu kumppanuudelle ja yhteistyölle. Sen vuoksi IFLA pitää tärkeänä, että kirjastot ymmärtävät mahdollisuutensa liittyä ohjelman aktiiviseksi tukijaksi ja toteuttajaksi ja samalla vaikuttaa poliittisiin päättäjiin omassa maassaan, että ohjelman tavoitteet myös toteutuisivat.

\section{Komiteatyö ja verkostoituminen}

Osallistuin taas komiteatyöhön, jossa laaditaan tulevalle konferenssille ohjelma ja varmis- 
tetaan, että kulumassa olevan konferenssin ohjelma toimii sovitulla tavalla. Aineistojen saatavuuteen ja jakamiseen keskittyvä komiteamme kävi myös vaalin luottamushenkilöistä.

Komiteatyö ja työskentely IFLAn hallinnollisissa elimissä on mielestäni keskeisin paikka vaikuttaa ja verkostoitua IFLAssa. Omassa ryhmässämme tärkeitä teemoja ovat olleet digitaalisten aineistojen va-

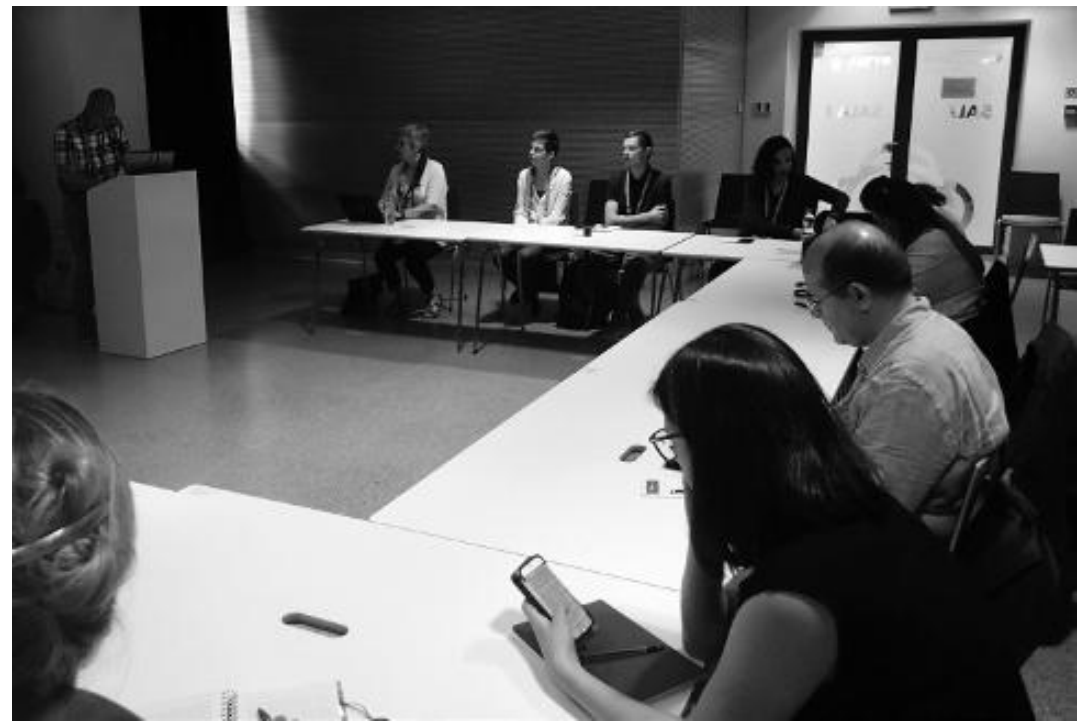

Komiteatyö käynnissä uuden puheenjohtajan johdolla paa liikkuvuu ja kirjastojen väliseen aineistojen käyttöön liittyvät asiat ja käytänteet.

Frederic Zarnt esitteli tähän liittyen järjestämässämme sessiossa digitaalisten aineistojen säilyttämiseen liittyviä käytäntöjä ja lainsäädäntöä. Zarnt kollegoineen on parhaillaan toistamassa vuonna 2014 tekemäänsä kyselyä aiheesta. Alustavien tulosten mukaan käytännöt vaihtelevat maittain ja aineistotyypeittäin. Zarntin mukaan Pohjoismaissa on kattavimmat menettelytavat varmistaa digitaalisena syntyneiden aineistojen säilyminen tuleville sukupolville.

Esiintyjät pitivät suurimpana haasteena tekniikan ja aineistotyyppien nopeaa muutosta ja kehittymistä sekä sitä, että digitaalisten aineistojen kattavaa säilytystä ei ole vieläkään saatu aikaiseksi. Yhteisille käytänteille ja erityisesti yhteiselle lainsäädännölle on huutava tarve koko maailmassa.

\section{Kohti Kuala Lumpuria}

Vuoden 2018 konferenssi järjestetään Kuala Lumpurissa Malesiassa. Teema on kirjastojen ja yhteiskunnan muutos tai muuttaminen, joka liittyy edellä kuvattuun IFLAn strategiatyöhön ja sitoutumiseen kestävälle kehitykselle perustuvan informaatioyhteiskunnan rakentamiseen. Kirjastojen rooli on tarjota kaikille ihmisille mahdollisuutta osallistua yhteiskuntaan: kirjastojen avoimuus digitaalisessa maailmassa on tärkeää.

Puolan konferenssi avasi silmiä Euroopan historiaan ja sitä kautta nykyiseen tilanteeseen. Kirjastojen ja ihmiskunnan yhteistyötä ja avoimuutta tarvitaan edelleen. Kirjastojen velvollisuus on muistuttaa, että ihmiskunta voi yhä toteuttaa tasa-arvoisen ja kestävän tulevaisuuden.

\section{Tietoa kirjoittajasta:}

